\title{
The Effect of Essential Amino Acid (Lysine) in Commercial Feed of Patin Catfish (Pangasius sp.)
}

\author{
Muhammad Ainul Yaqin, Agustono*, and Widya Lokapimasari \\ Department of Fish Health Management and Aquaculture, Faculty of Fisheries and Marine, Universitas Airlangga, Surabaya-60115, Indonesia \\ *Corresponding Author's Email: agustono@fpk.unair.ac.id; (DORCiD: 0000-0003-4416-7526
}

\begin{abstract}
The Patin catfish (Pangasius sp.) is a species of fish that is widely cultivated both in quarantine and in ponds. The success of Patin catfish cultivation is influenced by several factors, one of them is the feed. Patin catfish need essential amino acids to meet their needs. The addition of the amino acid (lysine) in the commercial feed not only affects the metabolism of the fish but also the content of Omega- 3 and Omega- 6 would be found in the fish. This study was conducted to observe the influences of essential lysine on the content of Omega- 3 and Omega- 6 of Patin catfish. This was an experimental study with a completely randomized design method, consisting of four treatments and five replications. The treatment which was given to experimental fish was commercial feed with the addition of lysine at different doses. The result indicated that the addition of lysine in commercial feed for 30 days of this research had a significant effect ( $\mathrm{p}<0.05)$ on the increase in the content of Omega-3 and Omega-6 in Patin catfish meat (Pangasius sp.). Based on the results of the current study, Patin catfish can be a good source of Omega-3 and omega 6 if the feed that is used in the cultivation process, contains lysine as an amino acid source.
\end{abstract}

Keywords: Cultivation, Lysine, Omega-3, Omega-6, Pangasius sp.

\section{INTRODUCTION}

The Patin catfish's need for essential amino acids is an important factor to be fulfilled in order to increase the Catfish quality. Essential amino acids are those amino acids that cannot be synthesized by animals or plants to generate maximum growth (Tom, 1998). The addition of essential amino acids to the commercial fish feed and how it affects the Patin catfish Omega-3 and Omega-6 content are interesting things to be explored and studied further.

The high consumption level of Patin catfish which is with the Latin name of Pangasius sp. Has become an interesting object to be observed. Among the many types of freshwater fish, Patin catfish is a fish with the highest level of proteins, with nutritional content of $16.08 \%$ protein, about $5.75 \%$ fat content, $1.5 \%$ carbohydrate, $0.97 \%$ ash, and 75.7\% water (Almunadi et al., 2001). When compared with the fat content of other freshwater fish such as Snakehead fish and Goldfish, Patin catfish has a higher fat content. Patin catfish have the potential to meet the food and nutrition needs of the community. The production of Patin catfish in Indonesia has increased from 2010 to 2013, which was 147,890 tons in 2010 and reached 972,779 tons in 2013 (Almunadi et al., 2001).

This increase in production raises the question of how the quality of the Patin catfish was produced by farmers. In this case, the quality of the content of Omega-3 and Omega-6 in Patin catfish which is widely consumed by the community has become an interesting factor to be discussed further. Omega- 3 and Omega- 6 belong to the group of essential fatty acids. Omega-3 has derivatives from ALA ( $\alpha$-Linolenic Acid), EPA (Eicosapentaenoic Acid), and DHA (Docosahexaenoic Acid). While Omega-6 is derived from LA (Linolenic Acid), and ARA (Arachidonic Acid, Panagan et al., 2012). Omega3 and Omega-6 which are contained in Patin catfish are influenced by the cultivation process itself, one of them is feeding (Oktavianawati et al., 2016).

Patin catfish need essential amino acids in their feed to meet their needs. One of the essential amino acids is lysine. The role of lysine is important in metabolism because lysine is used for protein synthesis as well as compiling other important components used for metabolism. Lysine is one of the essential amino acids needed by Patin catfish which plays a role in growth (Millamena et al., 2019). Lysine can increase fish growth because it can improve the balance of utilization of other amino acids (Alam et al., 2005). Therefore, research on the effect of the addition of essential amino acids like lysine in commercial feed with considering the content of Omega-3 and Omega-6 (essential fatty acids that have derived from Linoleic Acid (LA)) in Catfish needs to be done.

\section{MATERIALS AND METHODS}

\section{Ethical approval}

The present study was conducted at the Faculty of Fisheries and Marine, Universitas Airlangga, Surabaya, Indonesia in 2019. The current study was carried out in correspondence with the research principles based on basic 
principles of ethics of respect, beneficence, non-maleficence, and justice. All experimental protocols and procedures were approved by the Institutional Animal Care of Indonesia

\section{Experimental fish}

The experimental animals used in the study were Patin catfish with a size of $6-8 \mathrm{~cm}$ per head. The Patin catfish were randomly allotted to four treatment groups with five replicates per treatment, and 10 Patin catfish per replicate $(\mathrm{n}=$ 200).

\section{Experimental feed}

The feed which used in the current research was pellet-shaped. The essential amino acid which was lysine and tapioca flour were used as binders.

\section{Experimental equipment}

The equipment used in the study included 20 pieces of the aquarium in $30 \times 30 \times 40 \mathrm{~cm}$ size, aerator resun air pump LP-40, aeration hose, siphon hose, 20 pieces of the air stone, plastic bag, litmus paper to measure $\mathrm{pH}$, thermometer, $\mathrm{DO}$ meter, ammonia test kit, digital scales, tubular fiber for water reservoirs, ruler or caliper, stationery, fecal container bottles and feed scraps, basins, buckets, and fishnet.

\section{Experimental parameters}

The current experimental study aimed to determine the effect of certain parameters on groups of fish under controlled conditions. The experimental parameters in this study included independent parameters of lysine doses in the feed as $0 \%(\mathrm{P} 0), 1.2 \%(\mathrm{P} 1), 2.2 \%(\mathrm{P} 2)$, and $3.2 \%(\mathrm{P} 3)$. The dependent parameters in this study were the content of Omega-3 and omega-6. Finally, the controlled parameters entailed experimental fish in this study in the size of 6-8 $\mathrm{cm}$ per head.

\section{Measurement of Omega-6 and Omega-3 content}

Omega- 6 and Omega-3 content can be defined as the sum of eicosapentaenoic acid (EPA) and docosahexaenoic acid (DHA). The standard technique used for fatty acid analysis and quantification has been gas chromatography (GC) with flame ionization detection (Nazari et al., 2008).

\section{Supporting experimental parameters}

The supporting parameters of the study were water quality management parameters which included $\mathrm{pH}$, temperature, DO, and ammonia. Temperature and DO measurements were performed every day while ammonia was measured once every seven days.

\section{Data analysis}

The data were statistically analyzed using analysis of Variance (ANOVA 8.). ANOVA is a useful statistical model that simultaneously tests differences between means in more than two conditions (Boisgontier and Cheval, 2016). If significant results were obtained, the calculation would be continued with Duncan's Multiple Range Test with the accuracy of 5\%, to provide a significance level for the difference between the mean value of each pair (Salkind, 2010).

\section{RESULTS AND DISCUSSION}

Based on the results from the current study, it was found that the Omega-3 content of catfish (Pangasius sp.) ranged from 1,145 to $2,076 \%$ and Linoleic Acid (LA) (Omega-6) ranged from $13.821 \%$ to $22.149 \%$. Calculation of the content of Omega-3 and LA (Omega-6) has been presented in table 1.

The results of statistical analysis on Omega-3 content indicated a significant difference $(\mathrm{p}<0.05)$ between treatment groups. The lowest Omega-3 content in treatment was in P3 (1.145\%), while Omega-3 content in treatment P0 (1.814\%), P1 (2.076\%), and P2 (1.840\%) presented similar results. Based on the results from Duncan's Multiple Range Test (Duncan Multiple Distance Test), there was a significant difference between the results of the Omega-3 content of Patin catfish. The results of analyzed variances by ANOVA indicated a significant difference $(\mathrm{P}<0.05)$ between each treatment with the addition of lysine.

The results of Duncan's Multiple Range Test (Duncan Multiple Distance Test) expressed a significant difference. The P0, P1, and P2 treatment groups have the same Omega-6 content and were not significantly different, while treatment groups of P0, P1, and P2 were significantly different from P3 ( $p<0.05)$. The highest Omega- 6 content was found in treatment P3 $(22.540 \%)$. 
Table 1. The content of Omega-3 and Linoleic Acid (Omega-6) of treated catfish (Pangasius sp.).

\begin{tabular}{lcc}
\hline Treatment Group & Omega-3 Content \pm SD & LA Content \pm SD \\
\hline $\mathrm{P}_{0}$ & $1.814^{\mathrm{b}} \pm 0.343$ & $14.944^{\mathrm{a}} \pm 4.176$ \\
$\mathrm{P}_{1}$ & $2.076^{\mathrm{b}} \pm 0.122$ & $14.010^{\mathrm{a}} \pm 2.013$ \\
$\mathrm{P}_{2}$ & $1.840^{\mathrm{b}} \pm 0.224$ & $14.909^{\mathrm{a}} \pm 0.848$ \\
$\mathrm{P}_{3}$ & $1.145^{\mathrm{a}} \pm 0287$ & $22.540^{\mathrm{b}} \pm 3.555$ \\
\hline
\end{tabular}

Note: Different superscripts in the same column indicate a significant difference (p < 0.05). LA: Linoleic acid, P0: 0\% lysine, P1:1.2\% lysine, P2: $2.2 \%$ lysine, P3: $3.2 \%$ lysine.

\section{DISCUSSION}

Significant changes have been obtained in the content of Omega-3 and Omega-6 in Patin catfish which were given a certain amount of fish feed containing lysine.

Omega-3 is a PUFA that has many double bonds, the first double bond is located on the third carbon atom of the methyl omega group, the next double bond lies in methyl omega, the next double bond is located on the third carbon atom from the previous double bonds. The methyl omega group is the last group of fatty acid chains. The EPA has many benefits including lowering cholesterol and anti-inflammation, and EPA is needed to help the growth and development of nerve cells to be optimal (Maulana, 2013).

The present study indicated the results of an increase in the content of Omega- 3 in catfish meat after the administration of lysine in feed at a dose of $1.2 \%$ (P1) with an Omega-3 content of $2.076 \%$. It is suspected that the administration of amino acid lysine which acts as a precursor of carnitine could be absorbed optimally by catfish so that the content of EPA and DHA could increase. Carnitine plays a role in the transfer of long-chain fatty acids into the mitochondria to be oxidized, so that the content of EPA and DHA can also increase after the oxidation process. Omega-3 has an important role in growth, immune system, lower blood cholesterol levels, enhances the metabolism of cells, essential nutrient for the eyes, and good for the central nervous system and brain in fish (Greenwood et al., 2001).

Omega-6 is included in essential fatty acids which have Linoleic acid parent compounds or called Linoleic acid (LA). Omega-6 is a PUFA that has the first double bond in the 6th position. Linoleic acid is a precursor in the synthesis of PUFA. Linoleic acid is produced from plants, it is specifically contained in seed oil. In addition, Linoleic and Linolenic acids are found in food reserves. Arachidonic Acid (AA) which is one of the Omega-6 types, is often found in cell membranes, is an important compound in interacellular communication, and becomes a precursor compound for other important compounds in the body (Belitz et al., 2009). This study indicated an increase in the content of Omega-6 in Patin catfish meat after administration of lysine amino acid to feed at a dose of $3.2 \%$ (P3) which led to Omega-6 content of $22.540 \%$. The reason for this increase in content is the limited lysine availability and the imbalance in the composition of amino acids in the fish feed (Nunes et al., 2014). Feeds with an amino acid content of $<20 \%$ are more effective than feeds which their source of protein is only raw materials (Cowey, 1994).

Omega-6 (Linoleic acid and arachidonic acid) in Patin catfish meat is influenced by the addition of Lemuru fish oil to the commercial feed of catfish (Gonçalves et al., 2012). The Omega-6 content is found in meat because most unsaturated fatty acids are stored in phospholipids in the cell membrane. The function of Omega- 6 in Pangasius sp. is the formation of compounds such as hormones that are used as a carrier of orders from one cell to another nerve cell (Cuzon et al., 2004).

One of the supporting factors for the success of Patin catfish aquaculture is water quality. Water quality parameters observed during the present study were temperature, $\mathrm{DO}, \mathrm{pH}$, and ammonia (NH3). Patin catfish were kept in containers for 30 days with various water temperatures ranging from $27.4^{\circ} \mathrm{C}$ to $28.7^{\circ} \mathrm{C}$ and $\mathrm{DO}$ ranging from $4.47 \mathrm{mg} / \mathrm{L}$ to 7.08 $\mathrm{mg} / \mathrm{L}$. The catfish containers with different treatments and DO had similar $\mathrm{pH}$ of 7.0 and ammonia of $0.003 \mathrm{mg} / \mathrm{L} \mathrm{during}$ 30 days. The level of water quality in Patin catfish containers was in accordance with the limits of water quality parameters, namely temperature ranging from 28 to $32^{\circ} \mathrm{C}$, DO levels (3-6 ppm), water $\mathrm{pH}$ tolerated by catfish ( $\mathrm{PH}$ five to nine) (Khairuman and Dodi, 2002). NH3 which can still be tolerated by catfish is 1 ppm. Drastic temperature changes can cause stress in fish and stop the activity of Patin catfish in the waters. Fish need DO to perform activities such as swimming, reproduction, respiration, and growth (Buentello et al., 2000). Increased NH3 concentration is influenced by an increase in $\mathrm{pH}$ value and feeding amount (Effendi et al., 2007).

\section{CONCLUSION}

Based on the results from the current study, it can be concluded that the addition of lysine to commercial Patin catfish feed could increase the content of Omega-3 and Omega- 6 in catfish meat. Lysine addition at the dose of $1.2 \%$ could increase the content of Omega-3 namely Eicosapentaenoic Acid (EPA) and Docosahexaenoic Acid (DHA) and a 3.2\% dose of lysine could increase the content of Omega-6 namely Linoleic Acid (LA) and Arachidonic Acid (AA) in catfish meat. 


\section{DECLARATIONS}

\section{Authors' contribution}

Agustono designed the study, Yaqin collected the data and Lokapimasari wrote the manuscript. Finally, all of the authors approved the final draft of the manuscript for submission.

\section{Competing interests}

The authors have declared that no competing interest exists.

\section{Ethical considerations}

All authors approved the final draft of the manuscript for submission to this journal. Ethical issues (Including plagiarism, consent to publish, misconduct, data fabrication and/or falsification, double publication and/or submission, redundancy, etc.) have been checked by the authors.

\section{REFERENCES}

Alam MS, Teshima S, Koshio S, Ishikawa M, Uyan O, Hernandez LHH, and Michael FR (2005). Supplemental effects of coated methionine and/or lysine to soy protein isolate diet for juvenile kuruma shrimp, Marsupenaeus japonicus. Aquaculture, 248: 1319. Available at: https://www.sciencedirect.com/science/article/abs/pii/S0044848605002267

Almunadi T, Panagan YH, and Gultom JU (2001). Analasisi kualitatif dan kuantitatif asam lemak tak jenuh omega-3 dari minyak ikan patin (Pangasius pangasius) dengan metoda kromatografi gas. Jurnal Penelitian Sains, 14(4): 38-42. Available at: https://www.neliti.com/publications/168366/analisis-kualitatif-dan-kuantitatif-asam-lemak-tak-jenuh-omega-3-dari-minyak-ika

Belitz HD, Grosch W, and Schieberle P (2009). Food chemistry. Springer-Verlag, Berlin, pp. 158-247. Available at: https://www.springer.com/gp/book/9783540699330

Boisgontier MP, and Cheval B (2016). The ANOVA to mixed model transition. Neuroscience and Biobehavioral Reviews, 68: 10041005. DOI: https://www.doi.org/10.1016/j.neubiorev.2016.05.034

Buentello A, Gatlin DM, and Neill WH (2000). Effects of water temperature and dissolved oxygen on daily feed consumption, feed utilization and growth of channel catfish (Ictalurus punctatus). Aquaculture, 182: 339-352. DOI: https://www.doi.org/10.1016/S0044-8486(99)00274-4

Cowey CB (1994). Amino acid requirements of fish: a critical appraisal of present values. Aquaculture, 124: 1-11. Available at: https://www.sciencedirect.com/science/article/abs/pii/0044848694903492

Cuzon G, Lawrence A, Gaxiola G, Rosas C, and Guillaume J (2004). Nutrition of Litopenaeus vannamei reared in tanks or in ponds. Aquaculture, 235: 513-551. DOI: https://www.doi.org/10.1016/j.aquaculture.2003.12.022

Effendi IE, Bugri HJ, and Widanarni T (2007). Effect of different rearing density on survival rate and growth of giant gouramy osphronemus gouramy Lac. fry at size of $2 \mathrm{~cm}$ in length. Jurnal Akuakultur Indonesia, 5(2): 127-35. DOI: https://www.doi.org/10.19027/jai.5.127-135

Gonçalves LU, Ferroli F, and Viegas EMM (2012). Effect of the inclusion of fish residue oils in diets on the fatty acid profile of muscles of males and females lambari (Astyanax altiparanae). Revista Brasileira de Zootecnia, 41(9): 1967-1974. DOI: https://www.doi.org/10.1590/S1516-35982012000900001

Greenwood RH, Titgemeyer EC, Stokka GL, Drouillard JS, and Loest CA (2001). Effects of L-carnitine on nitrogen retention and blood metabolites of growing steers and performance of finishing steers. Journal of Animal Science, 79(1): 254-60. DOI: https://www.doi.org/10.2527/2001.791254x

Khairuman SP, and Dodi S (2002). Budi daya patin secara intensif. AgroMedia Pustaka: Jakarta. pp. 52-120. Available at: https://agromedia.net/katalog/budi-daya-patin-secara-intensif/

Maulana IT (2013). Pemisahan asam elaidat (trans-9-octadecenoic acid) dan asam lemak jenuh serta peningkatan kandungan EPA dan DHA dari minyak limbah perusahaan pengolahan ikan. tesis tidak dipublikasikan. Bandung: Sekolah Farmasi, Institut Teknologi Bandung. pp. 5-70 Available at: https://digilib.itb.ac.id/index.php/gdl/view/45374

Millamena O, Bautista-Teruel M, Reyes O, and Kanazawa A (2019). Requirements of juvenile marine shrimp, Penaeus monodon (Fabricius) for lysine and arginine. Aquaculture, 164: 95-104. Available at: https://www.sciencedirect.com/science/article/abs/pii/S0044848698001793

Nazari B, Sedigheh A, Nazila S, Saberi SA, and Noushin M (2008). Content of long chain omega-3 fatty acid composition in some Iranian canned fish. ARYA Atherosclerosis, 4: 93-97. Available at: http://arya.mui.ac.ir/index.php/arya/article/view/67

Nunes AJP, Sa MVC, Browdy CL, and Vazquez-Anon M (2014). Practical supplementation of shrimp and fish feeds with crystalline amino acids. Aquaculture, 431(20): 20-27. DOI: https://www.doi.org/10.1016/j.aquaculture.2014.04.003

Oktavianawati I, Andinata D, Isnaeni AN, Hermiastuti M, Rahmawati N, Handayani W, and Winata INA (2016). Effects of feeding diets containing Azolla pinnata and probiotics on the growth and nutritional content of patin Fish (Pangasius djambal). Agriculture and Agricultural Science Procedia, 9: 403-410. DOI: https://www.doi.org/10.1016/j.aaspro.2016.02.156

Panagan AT, Yohandini H, and Wulandari M (2012). Analisis kualitatif dan kuantitatif asam lemak tak jenuh omega-3, omega-6 dan karakterisasi minyak ikan patin (Pangasius pangasius). Jurnal Penelitian Sains, 15(3): 102-106. Available at: http://ejurnal.mipa.unsri.ac.id/index.php/jps/article/view/105/99

Salkind NJ (2010). Encyclopedia of research design. Thousand Oaks, California, pp. 45-129. DOI: https://www.dx.doi.org/10.4135/9781412961288

Tom L (1998). Nutritional and feeding of fish. Springer, USA, p. 245 . Available at: https://www.springer.com/gp/book/9781475711769 